\title{
Composition and Genoprotective Effect of the Flavonoidal Content of Lepidium sativum L. Methanolic Seed Extract against Cyclophosphamide- Induced DNA Damage in Mice
}

\author{
Iman AA Kassem ${ }^{1, *}$, Ayman A Farghaly ${ }^{2}$, Neveen S Ghaly' ${ }^{1}$ Zeinab M Hassan' ${ }^{1}$, Marian Nabil'
}

Iman AA Kassem ${ }^{1, *}$, Ayman A

Farghaly ${ }^{2}$, Neveen S Ghaly',

Zeinab M Hassan ${ }^{1}$, Marian Nabil ${ }^{1}$

'Chemistry of Natural Compounds

Department, National Research Centre,

Dokki 12622, Giza, EGYPT.

${ }^{2}$ Genetics and Cytology Department,

National Research Centre, Dokki 12622, Giza, EGYPT.

\section{Correspondence \\ Iman AA Kassem}

Chemistry of Natural Compounds Department, National Research Centre, Dokki 12622, Giza, EGYPT.

E-mail: i.a.a.kassem@hotmail.com

History

- Submission Date: 25-09-2019;

- Review completed: 10-10-2019;

- Accepted Date: 21-10-2019.

DOI : 10.5530/pj.2020.12.19

Article Available online

http://www.phcogj.com/v12/i1

\section{Copyright}

( $) 2020$ Phcogj.Com. This is an openaccess article distributed under the terms of the Creative Commons Attribution 4.0 International license.

\begin{abstract}
Background: Lepidium sativum L. (Family Brassicaceae) is known to possess different pharmacological properties. Objective: The genoprotective role of flavonoids of $L$. sativum methanolic seed extract (LSF) against cyclophosphamide (CP)-induced DNA damage, in somatic and germ cells of mice, as well as characterization of the flavonoidal content were carried out in this study. Chromosomal aberration analysis in somatic and germ cells were also included. Materials and Methods: Six mice groups were used for this study. Group 1 served as a negative control. Group 2 received oral LSF (100 mg/kg b.wt.) for 5 consecutive days. Group 3 served as a positive control by receiving a single intraperitoneal (i.p.) CP dose (20 mg/kg b.wt.). The three other groups were orally administered 25,50 and $100 \mathrm{mg} / \mathrm{kg}$ b.wt. LSF, respectively, for 5 consecutive days. On the last day of treatment, the three groups received i.p. injection of CP (20 mg/kg b.wt.). Flavonoids were identified using spectral analysis. Results: LSF inhibited DNA aberrations in mice caused by cyclophosphamide dose dependently in the three groups with significant difference in the two groups that received doses of 50 and $100 \mathrm{mg} / \mathrm{kg} \mathrm{b.wt}$. The chromosomal aberrations inhibitory indices were calculated as 18 and 31 in mice somatic cells and 27 and 48 in germ cells, respectively. LSF was found to contain the flavonoids kaempferol, quercetin, kaempferol-3-O-a-L-rhamnopyranoside, kaempferol-3-O-B-D-glucopyranoside, and quercetin-3-O-B-D-galactopyranoside. Conclusion: LSF inhibited the DNA damage induced by $\mathrm{CP}$ in somatic and germ cells of mice dose-dependently. The antioxidant properties associated with flavonoids might account for the genoprotective activity.
\end{abstract}

Key words: Antioxidant activity, Chromosomal abberations, Flavonoids, Lipidium sativum.

\section{INTRODUCTION}

Despite the great advances in modern medicinal scientific research, traditional medicine is still used in treating majority of diseases in developing countries. According to the World Bank in 1997, the significance and importance of medicines from natural origin have been increasing worldwide. Almost $50 \%$ of medicines present in the market all over the world are made of natural based materials. Medicinal herbs are likely to remain in high demand in the market due to the difficulty of synthetically preparing many active constituents of medicinal plants. ${ }^{1}$

Lepidium sativum L., also known as garden cress or garden pepperwort, is an important member of family Brassicaceae. It's a fast growing annual herb which is native to Egypt and west Asia but also widely cultivated in temperate climates. ${ }^{2}$ L. sativum possesses many different medicinal properties. ${ }^{1}$ The seed extract have been used in Indian traditional medicine since ancient times. ${ }^{3}$ It also shows many medicinal properties such as anticancer, ${ }^{4}$ antidiabetic, hypocholesterolemic, ${ }^{5-7}$ antihypertensive, ${ }^{8}$ antidiarrheal, antispasmodic, and laxative activities. ${ }^{9-10}$ It also has fracture healing, ${ }^{11}$ hepatoprotective, ${ }^{12}$ diuretic, ${ }^{13}$ as well as antimicrobial, anti-inflammatory, antipyretic and analgesic potentials. ${ }^{14,15}$ It was also reported that
L. sativum is effective in treatment of cough and bronchial asthma. ${ }^{16}$

Flavonoids exist in nature as diphenylpropanoids. In addition to their importance as an essential component in human diet, flavonoids were reported in literature to possess several pharmacological activities such as antioxidant, antiviral, antiinflammatory and antitumor activities. ${ }^{17}$ Flavonoids are also reported to be involved in preventing free radical-mediated cytotoxicity and lipid peroxidation, which are known to be associated with cell aging and chronic diseases. ${ }^{18}$

Human exposure to genotoxic agents has dramatically increased in the last decades. In our continuous interest in genoprotective constituents from natural origin, ${ }^{19}$ the current study was carried out to investigate the safety and the possible genoprotective role of flavonoids of $L$. sativum methanolic seed extract (LSF) against the genotoxic effect of CP in bone marrow and spermatocyte cells of mice.

\section{MATERIALS AND METHODS}

\section{Chemicals}

Cyclophosphamide (CP) was purchased from SigmaAldrich (St. Louis, MO, USA). All other chemicals used in extraction were purchased from ADWIC (Cairo, Egypt).

Cite this article: Kassem IAA, Farghaly AA, Ghaly NS, Hassan ZM, Nabil M. Composition and Genoprotective Effect of the Flavonoidal Content of Lepidium sativum L. Methanolic Seed Extract against Cyclophosphamide- Induced DNA Damage in Mice. Pharmacog J. 2020;12(1):124-30. 
Kassem, et al: Composition and Genoprotective Effect of the Flavonoidal Content of Lepidium sativum L. Methanolic Seed Extract against CyclophosphamideInduced DNA Damage in Mice

\section{Plant material}

Lipidium sativum L. seeds were purchased from Egyptian market in February 2018.

\section{Extraction, preparation of flavonoidal fraction (LSF) and isolation}

The seeds of $L$. sativum were left at room temperature $\left(35^{\circ} \mathrm{C}\right)$ to remove any moisture until no loss of weight was detected. The air-dried seeds $(350 \mathrm{~g})$ were defatted with $\mathrm{n}$-hexane then extracted with $\mathrm{CH}_{2} \mathrm{Cl}_{2}(3 \mathrm{X} 2 \mathrm{~L})$ followed by $\mathrm{MeOH}$ till exhaustion at room temperature. The combined methanolic extract was dried at $40{ }^{\circ} \mathrm{C}$ under reduced pressure to yield a yellowish brown residue $(22.2 \mathrm{~g})$. The residue was dissolved in $\mathrm{H}_{2} \mathrm{O}(0.2 \%)$, and the aqueous solution was passed through a $500 \mathrm{~g}$ chromatographic column packed with the polymer gel Diaion HP-20 (Mitsubishi, Tokyo, Japan). The column was then washed with distilled water for several times and elution was carried out using $25 \%, 50 \%$, $75 \%$ aqueous $\mathrm{MeOH}$ followed by $100 \% \mathrm{MeOH}$. The collected fractions were examined by silica gel thin layer chromatography (TLC) (Merck, Darmstadt, Germany) using the solvent systems $\mathrm{CH}_{2} \mathrm{Cl}_{2}-\mathrm{MeOH}(5: 1)$ and $\mathrm{CH}_{2} \mathrm{Cl}_{2}-\mathrm{MeOH}-\mathrm{H}_{2} \mathrm{O}$ (60:30:5) The fractions eluted from the HP-20 column with $50 \%$ and $75 \%$ aqueous methanol $(5.1 \mathrm{~g})$ were combined and proved to contain flavonoids (LSF) (TLC analysis and examination under UV light). The LSF fraction was kept in the refrigerator until use. Part of LSF ( $3.0 \mathrm{~g}$ ) was subjected to silica gel column chromatography. The column was eluted with $\mathrm{CH}_{2} \mathrm{Cl}_{2}$ followed by $\mathrm{CH}_{2} \mathrm{Cl}_{2}-\mathrm{MeOH}$ with increasing amount of $\mathrm{MeOH}$ to $15 \%$. A total of 35 fractions $25 \mathrm{ml}$ each were collected. The fractions were monitored by silica gel TLC plates using solvent system $\mathrm{CH}_{2} \mathrm{Cl}_{2}-\mathrm{MeOH}$ (5:1) and examined under UV light followed by spraying with $\mathrm{FeCl}_{3}$ reagent. Sub-fractions 4-7 (1.1 g) eluted by $5 \%$ aqueous methanol was subjected to preparative thin layer chromatography using $\mathrm{CH}_{2} \mathrm{Cl}_{2}-\mathrm{MeOH}$ (5:1) solvent system. The material from the observed two bands were repeatedly purified on Sephadex LH-20 column (25 g, Sigma) to yield kaempferol (15 $\mathrm{mg}$ ) and quercetin $(25 \mathrm{mg})$.The fractions eluted with $10 \%, 12 \%$ and $15 \% \mathrm{MeOH}$ were combined $(1.3 \mathrm{mg})$ and the combined fraction was subjected to repeated preparative silica gel TLC using solvent system $\mathrm{CH}_{2} \mathrm{Cl}_{2}-\mathrm{MeOH}-\mathrm{H}_{2} \mathrm{O}$ (60:30:5). The material from the three bands were repeatedly purified on Sephadex LH-20 column (25g) to yield kaempferol-3-O- $\alpha$-L-rhamnopyranoside (15 mg), kaempferol-3-O$\beta$-D-glucopyranoside (12 mg) quercetin-3-O- $\beta$-D-galactopyranosyl $(10 \mathrm{mg})$. The isolated flavonoids identified by observing their color behavior under UV light and comparing their spectral data with the literature values (Figure 1).

\section{Kaempferol (1)}

Amorphous yellow powder, UV $\lambda_{\max } \mathrm{nm}(\mathrm{MeOH}): 254 \mathrm{sh}, 268,322 \mathrm{sh}$, 365 ; +NaOMe: 275, 320, 412; $+\mathrm{AlCl}_{3}: 262 \mathrm{sh}, 270,352,426 ;+\mathrm{AlCl}_{3} / \mathrm{HCl}$ 260, 271, 350, 426; +NaOAc: 275, 300, 385; +NaOAc/ $\mathrm{H}_{3} \mathrm{BO}_{3} 269,295$ sh, 320 sh, 370. ${ }^{1} \mathrm{H}$ NMR (400 MHz, acetone-d6) $\delta: 12.04(1 \mathrm{H}, \mathrm{S}, \mathrm{OH}-5)$, $8.02\left(2 \mathrm{H}, \mathrm{d}, \mathrm{J}=8.9 \mathrm{~Hz}, \mathrm{H}-2^{\prime}, \mathrm{H}-6^{\prime}\right), 6.89\left(2 \mathrm{H}, \mathrm{d}, \mathrm{J}=8.9 \mathrm{~Hz}, \mathrm{H}-3^{\prime}, \mathrm{H}-5^{\prime}\right)$, $6.41(1 \mathrm{H}, \mathrm{d}, \mathrm{J}=2.0 \mathrm{~Hz}, \mathrm{H}-8), 6.14(1 \mathrm{H}, \mathrm{d}, \mathrm{J}=2.0 \mathrm{H}, \mathrm{H}-6)$.

\section{Quercetin (2)}

Amorphous yellow powder, UV $\lambda_{\max } \mathrm{nm}(\mathrm{MeOH}): 258,266 \mathrm{sh}, 299 \mathrm{sh}$, 360; +NaOMe: 272, 327, 416, + $\mathrm{AlCl}_{3}: 275,303 \mathrm{sh}, 430 ;+\mathrm{AlCl}_{3} / \mathrm{HCl} 271$, 300, 364 sh, 402, +NaOAc: $270,325,393 ;+\mathrm{NaOAc} / \mathrm{H}_{3} \mathrm{BO}_{3}: 262,298$, 387. ${ }^{1} \mathrm{H}$ NMR (400 MHz, DMSO-d $) \delta: 12.44(1 \mathrm{H}, \mathrm{S}, \mathrm{OH}-5), 7.62(1 \mathrm{H}$, $\left.\mathrm{d}, \mathrm{J}=2.0 \mathrm{~Hz}, \mathrm{H}-2^{\prime}\right), 7.50\left(1 \mathrm{H}, \mathrm{dd}, \mathrm{J}=6.7,2.0 \mathrm{~Hz}, \mathrm{H}-6^{\prime}\right), 6.85(1 \mathrm{H}, \mathrm{d}, \mathrm{J}=6.7$ Hz, H-5'), 6.36 (1H, d, J=1.5 Hz, H-8), 6.14 (1H, d, J=1.5 Hz, H-6).

\section{Kaempferol-3-O- $\alpha$-L-rhamnopyranoside (3)}

Amorphous yellow powder, UV $\lambda_{\max } \mathrm{nm}(\mathrm{MeOH}): 265,340,+\mathrm{NaOMe}$ : 275,$388 ;+\mathrm{AlCl}_{3}: 275,300$ sh, 347,$398 ;+\mathrm{AlCl}_{3} / \mathrm{HCl}: 275,300$ sh, 362 ; +NaOAc: 274,300 sh, 362; +NaOAc/ $/ \mathrm{H}_{3} \mathrm{BO}_{3}: 262,342 .{ }^{1} \mathrm{H}$ NMR $(400$ $\mathrm{MHz}$, acetone- $\left.\mathrm{d}_{6}\right) \delta: 12.67(1 \mathrm{H}, \mathrm{S}, \mathrm{OH}-5), 7.82(2 \mathrm{H}, \mathrm{d}, \mathrm{J}=8.4 \mathrm{~Hz}, \mathrm{H}-2$, H-6'), 6.99 (2H, d, J=8.4 Hz, H-3', H-5'), 6.43 (1H, d, J=2.3 Hz, H-8), $6.23(1 \mathrm{H}, \mathrm{d}, \mathrm{J}=2.3 \mathrm{~Hz}, \mathrm{H}-6), 5.49$ (1H, d, J=1.5 Hz, H-1" Rha); 2.29-3.31 (4H, H-2"-H-5"), 0.86 (3H, d, J=5.6 Hz, Me-6"). ${ }^{13} \mathrm{C}-\mathrm{NMR}(400 \mathrm{MHz}$, acetone- $\left.\mathrm{d}_{6}\right) \delta: 178.5$ (C-4), $164.4(\mathrm{C}-7), 162.3(\mathrm{C}-5), 160.2$ (C-4'), 157.7 (C-2), 157.2 (C-9), 134.9 (C-3), 130.8 (C-2',6'), 121.5 (C-1'), 115.5 (C3',5'), 104.9 (C-10), 101.9 (C-1"), 98.8 (C-6), 93.7 (C-8), 71.3 (C-4"), 70.7 (C-3"), 70.6 (C-2"), 70.6 (C-5"), 16.9 (C-6").

\section{Kaempferol-3-O- $\beta$-D-glucopyranoside (4)}

Amorphous yellow powder, UV $\lambda_{\max } \mathrm{nm}(\mathrm{MeOH}): 265,300 \mathrm{sh}, 351$; +NaOMe: 273, 322 sh, 404; $+\mathrm{AlCl}_{3}: 275,301$ sh, 345, 400; $+\mathrm{AlCl}_{3} / \mathrm{HCl}$ : 273, 347, 402; +NaOAc: 271, 371; +NaOAc/H3BO3: 264, 351. ${ }^{1} \mathrm{H}$ NMR $\left(400 \mathrm{MHz}, \mathrm{DMSO}-\mathrm{d}_{6}\right) \delta: 12.60(1 \mathrm{H}, \mathrm{S}, \mathrm{OH}-5), 8.04(2 \mathrm{H}, \mathrm{d}, \mathrm{J}=8.8 \mathrm{~Hz}$, H-2', H-6'), 6.88 (2H, d, J=8.8 Hz, H-3', H-5'), 6.33 (1H,d, J=1.8 Hz, $\mathrm{H}-8), 6.12(1 \mathrm{H}, \mathrm{d}, \mathrm{J}=1.8 \mathrm{~Hz}, \mathrm{H}-6), 5.43(1 \mathrm{H}, \mathrm{d}, \mathrm{J}=7.3 \mathrm{~Hz}, \mathrm{H}-1$ " Glc). 3.07-3.60 (sugar protons). ${ }^{13} \mathrm{C}-\mathrm{NMR}\left(400 \mathrm{MHz}, \mathrm{DMSO}-\mathrm{d}_{6}\right) \delta: 177.55$ (C-4), 161.60 (C-7), 160.42 (C-5), 157.03 (C-9), 156.29 (C-2), 133.54 (C-3), 131.27 (C-2',6'), 121.40 (C-1'), 115.56 (C-3',5'), 103.8 (C-10), 101.53 (C-1"), 99.69 (C-6), 94.38 (C-8), 77.93 (C-5”), 76.91 (C-3"), 74.69 (C-2"), 70.34 (C-4"), 61.30 (C-6").

\section{Quercetin-3-O- $\beta$-D-galactopyranoside (5)}

Amorphous yellow powder, UV $\lambda \mathrm{nm}(\mathrm{MeOH}): 257,268 \mathrm{sh}, 363$; +NaOMe: 273, 323 sh, 409; $+\mathrm{AlCl}_{3}: 272,304 \mathrm{sh}, 437 ;+\mathrm{AlCl}_{3} / \mathrm{HCl}: 273$, 348,405 ; +NaOAc: $273,324,375 ;+\mathrm{NaOAc} / \mathrm{H}_{3} \mathrm{BO}_{3}: 265,298,377 .{ }^{1} \mathrm{H}$ NMR (400 MHz, DMSO-d $) \delta: 12.63(1 \mathrm{H}, \mathrm{S}, \mathrm{OH}-5), 7.67(1 \mathrm{H}, \mathrm{dd}, \mathrm{J}=$ 2.2, $\left.8.5 \mathrm{~Hz}, \mathrm{H}-6^{\prime}\right), 7.53\left(1 \mathrm{H}, \mathrm{d}, \mathrm{J}=2.2 \mathrm{~Hz}, \mathrm{H}-2^{\prime}\right), 6.83(1 \mathrm{H}, \mathrm{d}, \mathrm{J}=8.5 \mathrm{~Hz}$, $\left.\mathrm{H}-5^{\prime}\right), 5.38\left(1 \mathrm{H}, \mathrm{d}, \mathrm{J}=7.6 \mathrm{~Hz}, \mathrm{H}-1^{\prime \prime}\right) 3.08-3.60$ (sugar protons). $6.41(1 \mathrm{H}$, d, J=2.0 Hz, H-8), $6.20(1 \mathrm{H}, \mathrm{d}, \mathrm{J}=2.0 \mathrm{~Hz}, \mathrm{H}-6) .{ }^{13} \mathrm{C}-\mathrm{NMR}(400 \mathrm{MHz}$, DMSO-d $\left.{ }_{6}\right)$ : 177.94 (C-4), 164.61 (C-7), 161.69 (C-5), 156.76 (C-9), 156.68 (C-2), 148.93 (C-4'), 145.29 (C-3'), 133.94 (C-3), 122.46 (C-6'), 121.55 (C-1'), 116.39 (C-5'), 115.64 (C-2'), 104.37 (C-10), 102.25 (C1"), 99.13 (C-6), 93.96 (C-8), 76.30 (C-5”), 73.64 (C-3"), 71.66 (C-2"), 68.38 (C-4"), 60.59 (C-6")

\section{Animals}

Male white Swiss mice (Mus musculus), aged from 9 to 12 weeks were used in all experiments. The animals were obtained from a closed

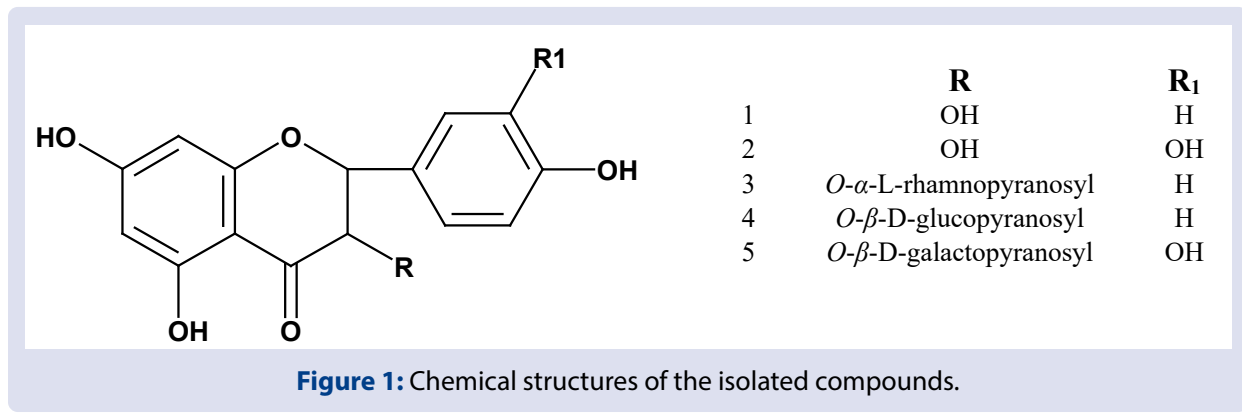


random bred colony at the National Research Centre (Giza, Egypt). The mice used for each experiment were of similar age ( \pm 1 week) and weight $( \pm 2 \mathrm{~g})$. Animals were housed in polycarbonate boxes with steelwire tops and bedded with wood shavings. Ambient temperature was controlled at $22 \pm 3{ }^{\circ} \mathrm{C}$ with a relative humidity of $50 \pm 15 \%$ and a $12 \mathrm{~h}$ light/dark photoperiod. Food and water were provided ad libitum. The experiments were conducted according to the Animal Research Ethical Committee Guidelines of the National Research Centre.

\section{Experimental design}

A total of 30 mice were used for the experimental model. Mice were divided into six groups each consists of five animals. The animals were treated as follows:

Group 1 served as the non- treated, negative control. Group 2 received oral LSF by gavage $(100 \mathrm{mg} / \mathrm{kg}$ b.wt.) for 5 consecutive days. Group 3 served as the positive control by receiving a single intraperitoneal (i.p.) dose of CP $(20 \mathrm{mg} / \mathrm{kg}$ b.wt.). Groups 4,5 and 6 were orally administered LSF at doses of 25, 50 and $100 \mathrm{mg} / \mathrm{kg}$ b.wt. respectively for 5 consecutive days. On the last day of treatment, the three groups received i.p. injection of CP at a dose of $20 \mathrm{mg} / \mathrm{kg}$ b.wt. Samples were collected $24 \mathrm{~h}$ after the last treatment.

\section{Cytogenetic analysis}

\section{Chromosomal aberrations in somatic cells}

Chromosomal preparations from bone marrow (somatic cells) were prepared according to Yosida and Amano method. ${ }^{20}$ One hundred well-spread metaphases per mouse were analysed. Metaphases with gaps, chromosome or chromatid breakage, fragmentation, deletions, Robertsonian translocation, as well as numerical aberrations (polyploidy) were recorded.

\section{Chromosomal abnormalities in germ cells}

Spermatocytes (germ cells) chromosomal preparations were carried out according to the technique of Evans et al. ${ }^{21}$ One hundred well-spread diakinase- metaphase I cells were analysed per animal for chromosomal aberrations. Metaphases with univalents, fragments, and chromosome translocations were recorded. Mice were injected i.p. with colchicine 2-3 $\mathrm{h}$ before animal sacrifice. Metaphases analysed under100X magnification with a light microscope (Olympus, Saitama, Japan).

\section{Statistical analysis}

The t-test was used to calculate the significance of the results of the chromosomal aberrations between the group which received the $\mathrm{CP}$ alone compared with those of the negative control group and the group which received CP with LSF. Statistical significance was taken as $p$ values less than 0.01 for all experiments.

Evaluation of the activity of the LSF to reduce abnormalities induced by $\mathrm{CP}$ was carried out according to the following formula: ${ }^{22}$

Inhibitory index $(\mathrm{II})=[1-(\mathrm{GCME}$ plus $\mathrm{CP}-$ control $) /(\mathrm{CP}-$ control $)]$ X 100 .

\section{RESULTS}

\section{Isolation and characterization of flavonoids}

Five known flavonoids were isolated and characterized by spectroscopic techniques.

\section{Chromosomal aberrations in bone marrow cells}

The results in Table 1 showed the number and percentage of the chromosomal aberrations recorded for the animal treated groups: control, LSF, CP and LSF with CP in bone marrow cells (Figure 2). The percentage of aberrant cells in mice treated with LSF at $100 \mathrm{mg} / \mathrm{kg}$ b.wt. for 5 consecutive days $(2.20 \pm 0.40)$ showed no significant difference from that of the negative control group $(2.00 \pm 0.55)$. The results also showed the ability of the used doses of LSF to significantly reduce the aberrations induced by CP $(p>0.01)$ in mice bone marrow cells in a dose dependent manner. The percentage of total abnormal metaphases were reduced from $23.80 \pm 0.45$ in the group that received $\mathrm{CP}$ alone to $17.00 \pm 0.65$ upon pretreatment with $100 \mathrm{mg}$ LSF / kg b.wt. (excluding gaps).

Table 1: The inhibitory effect of flavonoidal content of the Lipidium sativum L. methanolic seed extract (LSF) on CP-induced chromosomal aberrations in mouse bone marrow cells in vivo.

\begin{tabular}{|c|c|c|c|c|c|c|c|c|c|c|}
\hline \multirow{3}{*}{$\begin{array}{l}\text { Treatments } \\
\text { (mg/kg b.wt.) }\end{array}$} & \multicolumn{3}{|c|}{ Total Abnormal Metaphases } & \multicolumn{6}{|c|}{ No. of different types of metaphases } & \multirow{3}{*}{$\begin{array}{l}\text { Inhibitory index } \\
\text { Excluding Gaps } \\
\text { (II) }\end{array}$} \\
\hline & \multirow[b]{2}{*}{ Number } & \multicolumn{2}{|c|}{ Mean $(\%) \pm S E$} & \multirow[b]{2}{*}{ G. } & \multirow{2}{*}{$\begin{array}{l}\text { Frag. and/ } \\
\text { or } \mathrm{Br} \text {. }\end{array}$} & \multirow[b]{2}{*}{ Del. } & \multirow[b]{2}{*}{ C.F. } & \multirow[b]{2}{*}{ M.A. } & \multirow[b]{2}{*}{ Polyp. } & \\
\hline & & Including Gaps & $\begin{array}{c}\text { Excluding } \\
\text { Gaps }\end{array}$ & & & & & & & \\
\hline 1. - ve Control & 15 & $3.0 \pm 0.40$ & $2.00 \pm 0.55$ & 5 & 8 & 2 & 0 & 0 & 0 & - \\
\hline 2. CP (20) & 134 & $26.80 \pm 0.50^{\mathrm{a}}$ & $23.80 \pm 0.45^{\mathrm{a}}$ & 15 & 55 & 12 & 7 & 41 & 4 & - \\
\hline 3. LSME (100) & 19 & $3.80 \pm 0.68$ & $2.20 \pm 0.40$ & 8 & 9 & 2 & 0 & 0 & 0 & - \\
\hline $\begin{array}{l}\text { 4. LSME + CP } \\
\text { a) } 25\end{array}$ & 126 & $25.20 \pm 0.70^{\mathrm{a}}$ & $22.00 \pm 0.54^{\mathrm{a}}$ & 16 & 61 & 10 & 2 & 35 & 2 & 8 \\
\hline b) 50 & 112 & $22.40 \pm 0.54^{\mathrm{ab}}$ & $19.80 \pm 0.52^{\mathrm{ab}}$ & 13 & 58 & 7 & 1 & 31 & 2 & 18 \\
\hline c) 100 & 98 & $19.60 \pm 0.50^{\mathrm{ab}}$ & $17.00 \pm 0.65^{\mathrm{ab}}$ & 13 & 45 & 5 & 3 & 32 & 0 & 31 \\
\hline
\end{tabular}

Total number of examined metaphases 500 (5 animals/group); G.: Gap; Frag.: Fragments; Br.: Breaks; Del.: Deletions; C.F.: Centric Fusions; M.A.: Multiple Aberrations; Polyp: Polyploidy. a: Significant compared to -ve control ( $p<0.01)$; b: Significant compared to CP treatment $(p<0.01)$ ( $\mathrm{t}$-test). 
Kassem, et al: Composition and Genoprotective Effect of the Flavonoidal Content of Lepidium sativum L. Methanolic Seed Extract against CyclophosphamideInduced DNA Damage in Mice

Table 2: The inhibitory effect of flavonoidal content of the Lipidium sativum methanolic seed extract (LSF) on CP-induced chromosomal abnormalities in mouse spermatocyte cells in vivo.

\begin{tabular}{|c|c|c|c|c|c|c|c|c|}
\hline \multirow[b]{2}{*}{$\begin{array}{l}\text { Treatments } \\
\text { (mg/kg b.wt.) }\end{array}$} & \multicolumn{2}{|c|}{ Total Abnormal Metaphases } & \multicolumn{5}{|c|}{ No. of different types of metaphases } & \multirow[b]{2}{*}{$\begin{array}{l}\text { Inhibitory index } \\
\text { (II) }\end{array}$} \\
\hline & Number & Mean(\%) \pm SE & XY-uni. & Auto.uni. & $\begin{array}{l}\text { XY-uni.+ Auto. } \\
\text { uni. }\end{array}$ & Frag. & Chain (IV) & \\
\hline 1. - ve Control & 14 & $2.80 \pm 0.50$ & 9 & 5 & 0 & 0 & 0 & 0 \\
\hline 2. $\mathrm{CP}(20)$ & 78 & $15.60 \pm 0.55^{\mathrm{a}}$ & 48 & 23 & 3 & 2 & 2 & 0 \\
\hline 3. LSME (100) & 16 & $3.20 \pm 0.48$ & 12 & 4 & 0 & 0 & 0 & 0 \\
\hline \multicolumn{9}{|l|}{ 4. $\mathrm{LSME}+\mathrm{CP}$} \\
\hline a) 25 & 69 & $13.80 \pm 0.60^{\mathrm{a}}$ & 46 & 15 & 4 & 1 & 3 & 14 \\
\hline b) 50 & 61 & $12.20 \pm 0.50^{\mathrm{ab}}$ & 34 & 24 & 1 & 0 & 2 & 27 \\
\hline c) 100 & 47 & $9.40 \pm 0.55^{\mathrm{ab}}$ & 30 & 13 & 1 & 1 & 2 & 48 \\
\hline
\end{tabular}

Total number of examined metaphases 500 ( 5 animals/ group); XY-uni: XY- univalent; Auto. uni.: Autosomal univalent; XY-uni.+ Auto. uni.: XY-univalent + Autosomal univalent; Frag.: Fragment. a: Significant compared to -ve control $(p<0.01)$; b: Significant compared to CP treatment $(p<0.01)(\mathrm{t}-\mathrm{test})$.

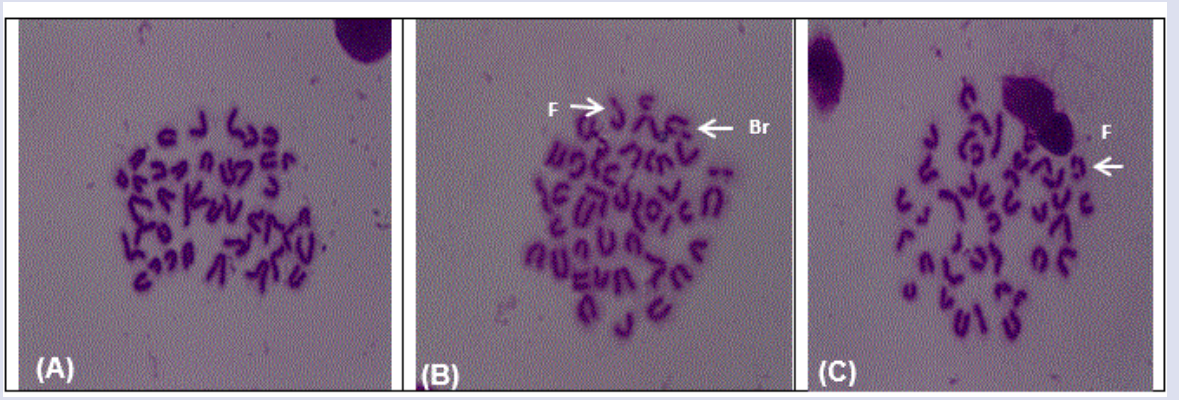

Figure 2: Chromosomal abnormalities in bone marrow cells in mice showing (A) normal, (B) fragment and break, and (C) fragment.

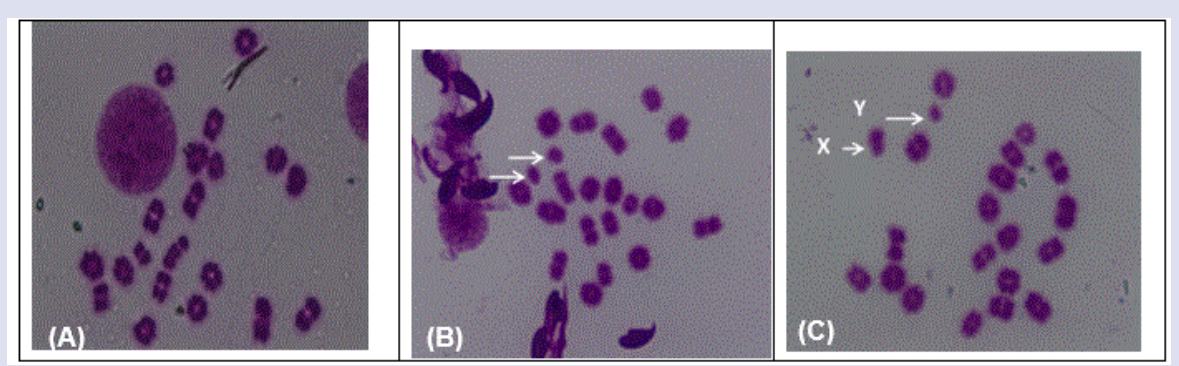

Figure 3: Chromosomal abnormalities in diakinase- metaphase 1 cells in mice showing (A) normal, (B) autosomal univalent and (C) XY univalent.

\section{Chromosomal aberrations in spermatocyte cells}

The effect of LSF on CP induced DNA damage in mice spermatocyte cells was determined by the percentage of chromosomal aberrations recorded in Table 2 (Figure 3). The percentage of chromosomal aberrations in spermatocyte cells showed significant elevation $(p<0.01)$ in CP treated group compared to negative control group. Oral administration of LSF at the three different doses 25,50 and $100 \mathrm{mg} /$ $\mathrm{kg}$ b.wt. for 5 consecutive days reduced DNA damage induced by CP in a dose dependent manner. The inhibitory indices were $14 \%, 27 \%$ and $48 \%$, respectively, with significant results $(p<0.01)$ in the two groups treated with the highest two dose levels.

\section{DISCUSSION}

In the present study, five flavonoids were isolated after Diaion HP-20 and silica gel column chromatography from the methanolic seed extract of L. sativum L (Figure 1). The flavonoids were identified as kaempferol, quercetin, kaempferol-3-O- $\alpha$-L-rhamnopyranoside, kaempferol-3-O$\beta$-D-glucopyranoside, and quercetin-3-O- $\beta$-D-galactopyranoside by comparison of their spectral data with the literature values. ${ }^{23-26}$ The flavonoidal content was then evaluated for its protective activity against genotoxicity induced by cyclophosphamide

Cyclophosphamide [N,N-bis(2-chloroethyl) tetrahydro-2H-1,3,2oxphosphorin-2-amine, 2-oxide monohydrate], the pharmaceutical product also known as cytoxan or endoxan, is an antineoplastic agent which is used in treatment of a vast range of cancers such as leukemia, ovarian adenocarcinoma and some types of lung cancers. It is also used as an immunosuppressant agent in treatment of arthritis, systemic lupus erythematosus, multiple sclerosis, and organ transplantation. ${ }^{27,28}$ Like many anticancer agents, $\mathrm{CP}$ fails to differentiate between normal cells and cancerous cells thus it causes the death of both. ${ }^{29}$ Extensive studies showed that $\mathrm{CP}$ is a powerful mutagen and/or clastogen at all phylogenetic levels despite being a powerful chemotherapeutic agent. It causes dose related increase in genotoxic activities in vivo leading to the onset of different pathological conditions such as cancer. Such genotoxic activities were described as cross links and strand breaks in DNA, gene mutations, chromosomal aberrations, sister chromatid exchanges in addition to increased DNA adduct formation. . $927,28,30^{2}$

L. sativum seeds are known for their nutritional importance and multiple health benefits. ${ }^{18}$ The safety of the seeds was previously 
evaluated in Wistar rats. Also, the acute and subchronic toxicity studies revealed that ingestion of $L$. sativum seeds for 14 consecutive days induced no toxic effects in rats in both cases. ${ }^{31}$ In the present study mice groups intaperitoneally injected with $20 \mathrm{mg} / \mathrm{kg}$ b.wt. CP showed statistically significant elevation $(p<0.01)$ in the percentage of chromosomal abnormalities in both bone marrow and spermatocytes cells when compared to the negative control mice group (Figures 2 and 3). The results also showed that the daily oral treatment of mice for 5 consecutive days with LSF at a dose of $100 \mathrm{mg} / \mathrm{kg}$ b.wt. caused non-significant effect in the percentage of chromosomal abnormalities in somatic and germ cells compared with the negative control group. Further, the animal groups which were orally administered LSF at the three dose levels 25,50 and $100 \mathrm{mg} / \mathrm{kg}$ b.wt. for 5 consecutive days followed by CP injection, showed a decrease in the percentage of DNA chromosomal aberrations in bone marrow and spermatocyte cells in a dose-dependent manner in comparison with the group injected only with CP. Mice groups treated with 50 and $100 \mathrm{mg} / \mathrm{kg}$ b.wt. showed significant inhibitory effects against DNA chromosomal aberrations with $18 \%$ and $31 \%$ in bone marrow cells as well as $27 \%$ and $48 \%$ in spermatocytes, respectively (Tables 1 and 2).

The effect of variable $L$. sativum extracts in reducing the damage caused by genotoxic chemicals was previously described. Mice treated with benzo(a)pyrene ( $\mathrm{BaP})$ after administration with $L$. sativum seed oil showed a decrease in germ cells genotoxicity which were indicated by a decrease in DNA damage, sperm abnormalities and lipid peroxidation level in addition to an increase in sperm counts, motility and GSH content. The results also showed that the seed oil improved the epididymal sperm quality, attenuated the testicular spermatogenic cell damage, restored the sperm counts and decreased the incidence of sperms with head abnormalities. ${ }^{32}$ Also L. sativum juice was investigated for its chemoprotective activities against 2-amino-3-methyl-imidazo [4,5-f] quinolone-induced genotoxic effects and colonic preneoplastic lesions using single cell gel electrophoresis assays and aberrant crypt foci experiments, respectively. ${ }^{33}$ Moreover, $L$. sativum juice was shown to protect against $\mathrm{B}(\mathrm{a}) \mathrm{P}$-induced DNA damage in human derived cells and the effects were not attributed due to their content of isothiocyanates. ${ }^{34}$

The role of the flavonoids kaempferol, querecetin or their glycosides as genoprotective and antigenotoxic natural substances, was previously discussed. The antigenotoxic activity of quercetin was reported and attributed mainly to its ability to protect against oxidative stress and inhibiting enzymes responsible for bioactivation of genotoxic agents that caused major oxidative DNA injury. ${ }^{35}$ Further biochemical studies suggested that DNA protective role of quercetin was based on enhancement of antioxidant defense system reduced glutathione (GSH) level, catalase (CAT) and glutathione peroxidase (GPx) activities with reduction in oxidative stress parameters such as thiobarbituric acidreacting substance (TBARS), by deoperoxides and NO levels. ${ }^{36,37}$ Kaempferol was shown to exhibit moderate antimutagenic effect. Glycosilation at C-3 showed no significant influence on glycosylated flavonoid antimutagenic activity. ${ }^{38,39}$

The antioxidant potentials of L. sativum seed extracts and their positive role in DNA repair system were previously discussed. ${ }^{40}$ The free radical scavenging activity of the $L$. sativum seed methanolic extract was investigated and it was concluded that free radical scavenging activity of the extract may be attributed to the polyphenolic compounds which have the ability to scavenge free radicals and enhance the DNA repair system or DNA synthesis. ${ }^{32,41}$ Also, Malar et al., ${ }^{42}$ showed that the ethanolic extracts of L. sativum seed extract exhibited high antioxidant activities and therefore form a potential source of natural antioxidant compounds.

Since CP was reported to cause oxidative stress in mice, increase the lipid peroxidation and decrease the anti-oxidant enzyme superoxide dismutase leading to generation of oxidative products, we concluded that the antioxidant properties of the LSF may account for its genoprotective activity.

\section{CONCLUSION}

In summary, the results of the present study showed that the flavonoidal content of $L$. sativum caused non-significant effect in the percentage of chromosomal abnormalities in somatic and germ cells. Moreover it inhibited the DNA damage induced by CP in bone marrow cells and spermatocytes of mice in a dose dependent manner and this inhibition might be attributed to its antioxidant properties. The obtained results need further investigations to open the door for possible development of new drugs from natural origin.

\section{CONFLICTS OF INTEREST}

\section{None.}

\section{REFERENCES}

1. Shail, Manjari D, Neeraj K, Gupta LN. Nutritional importance of Lepidium sativum L. (Garden cress/Chandrashoor): A review. Int J Pharm Anal Res. 2016;5(1):152-60.

2. Chatoui K, Talbaoui A, Aneb M, Bakri Y, Harhar H, Tabyaoui M. Phytochemical screening, antioxidant and antibacterial activity of Lepidium sativum seeds from Morocco. J Mater Environ Sci. 2016;7(8):2938-46.

3. Mali RG, Mahajan SG, Mehta AA. Studies on bronchodilatory effect of Lepidium sativum against allergen induced bronchospasm in guinea pigs. Pharmacog Mag. 2008:4(15):189-92.

4. Mahassni SH, Al-Reemi RM. Cytotoxic effect of an aqueous extract of Lepidium sativum L. seeds on human breast cancer cells. Indian J Trad Know. 2013;12(4):605-14.

5. Chauhan K, Sharma S, Agarwal N, Chauhan S, Chauhan B. A study on potential hypoglycemic and hypolipidemic effects of Lepidium sativum (Garden cress) in alloxan induced diabetic rats. Am J Pharm Tech Res. 2012;2:522-35.

6. Attia ES, Amer AH, Hasanein MA. The hypoglycemic and antioxidant activities of garden cress (Lepidium sativum L.) seed on alloxan-induced diabetic male rats. Nat Prod Res. 2019;33(6):901-5

7. Amawi K, Aljamal A. Effect of Lepidium sativum on lipid profiles and blood glucose in rats. J Physiol Pharmacol Adv. 2012;2(8):277-81.

8. Maghrani M, Zeggwagh NA, Michel JB, Eddouks M. Antihypertensive effect of Lepidium sativum $\mathrm{L}$. in spontaneously hypertensive rats. J Ethnopharmacol. 2005; 100(1-2):193-7.

9. Rehman N, Mehmood MH, Alkharfy KM, Gilani AH. Prokinetic and laxative activities of Lepidium sativum seed extract with species and tissue selective gut stimulatory actions. J Ethnopharmacol. 2011;134(3):878-83.

10. Rehman N, Mehmood MH, Alkharfy KM, Gilani AH. Studies on antidiarrheal and antispasmodic activities of Lepidium sativum crude extract in rats. Phytothe Res. 2012a;26(1):136-41.

11. Yadav $Y C$, Jain A, Srivastava DN, Jain A. Fracture healing activity of ethanolic extract of Lepidium sativum L. seeds in internally fixed rats' femoral osteotomy model. Int J Pharm Pharm Sci. 2011;3(2):193-7.

12. Abuelgasim Al, Nuha HS, Mohammed AH. Hepatoprotective effect of Lepidium sativum against carbon tetrachloride induced damage in rats. Res J Anim Vet Sci. 2008;3:20-3.

13. Patel U, Kulkarni M, Undale $V$, Bhosale A. Evaluation of diuretic activity of aqueous and methanol extracts of Lepidium sativum garden cress (Cruciferae) in Rats. Trop J Pharm Res. 2009:8(3):215-9.

14. Alqahtanin FW, Aleanizy FS, Mahmoud AZ, Farshori NN, Alfaraj R, Al-shedd ES, Alsarra IA. Chemical composition and antimicrobial, antioxidant, and anti-inflammatory activities of Lepidium sativum seed oil. Saudi J Biol Sci. 2019;26(5):1089-92.

15. Al-yahya MA, Mossa JS, Ageel M, Rafatullah S. Pharmacological and safety evaluation studies on Lepidium sativum L. seeds. Phytomedicine. 1994:1:155-

16. Rehman N, Khan A, Alkharfy KM, Gilani AH. Pharmacological basis for the medicinal use of lepidium sativum in airways disorders. Evid-Based Complement Altern Med. 2012b;1-8.

17. Barcelos GRM, Grotto D, Angeli JPF, Serpeloni JM, Rocha BA, Bastos JK, et al. Evaluation of antigenotoxic effects of plant flavonoids quercetin and rutin on HepG Cells. Phytother Res. 2011;25:1381-8. 
18. Bravo L. Polyphenols: chemistry, dietary sources, metabolism, and nutritional significance. Nutr Rev. 1998;56:317-33.

19. Melek FR, Aly FA, Kassem IAA, Abo-Zeid MAM, Farghaly AA, Hassan ZM Three further triterpenoid saponins from Gleditsia caspica fruits and protective effect of the total saponin fraction on cyclophosphamide-induced genotoxicity in mice. Z Naturforsch C. 2015;70(1-2):31-7.

20. Yosida H, Amano K. Autosomal polymorphism in laboratory bred and wild Norway rats, Rattus norvegicus. Chromosoma. 1965;16:658-67.

21. Evans EP, Breckon G, Ford CE. An air-drying method for meiotic preparations for mammalian testes. Cytogenetics. 1964;(3):289-94.

22. Madrigal-Bujaidar E, Diaz Barriga S, Cassani M, Márquez $P$, Revuelta P. In vivo and in vitro antigenotoxic effect of nordihydroguaiaretic acid against SCEs induced by methyl methanesulfonate. Mutat Res. 1998;419:163-8.

23. Ghaly NS, Melek FR, Abdelwahed NAM. Flavonoids from Albizia chinensis of Egypt. Rev Latinoam Quim. 2010;38(3):153-8.

24. Mabry TJ, Markham KR, Thomas MB. The systematic identification of the flavonoids. New York: Springer-Verlag, 1970.

25. Markham KR, Ternai B, Stanley R, Geiger H, Mabry TJ. Carbon-13 NMR studies of flavonoids-III: Naturally occurring flavonoid glycosides and their acylated derivatives. Tetrahedron. 1978;34:1389-97.

26. Melek FR, Ghaly NS, El-Kady M, Nabil M. Flavonoids from Albizia procera. Egypt J Pure App Sci. 2011;79-82.

27. Anderson D, Bishop JB, Garner RC, Ostrosky-Wegman P, Selby PB Cyclophosphamide. Review of its mutagenicity for an assessment of potential germ cell risks. Mutat Res. 1995;330(1-2):115-81.

28. McCarroll N, Keshava N, Cimino M, Chu M, Dearfield K, Keshava C, et al. An evaluation of the mode of action framework for mutagenic carcinogens case study: cyclophosphamide. Environ Mol Mutagen. 2008;49:117-31.

29. Codrington $A M$, Hales $B F$, Robaire B. Spermiogenic germ cell phase-specific DNA damage following cyclophosphamide exposure. J Androl. 2004;25(3):35462.

30. Abdella E. Bacterial lipopolysaccharides pretreatment protects against mutagenic and immunosuppressor effects of cyclophosphamide in mice. Iran J Cancer Prev. 2008;4(1):155-65.

31. Datta PK, Diwakar BT, Viswanatha S, Murthy KN, Naidu KA. Safety evaluation studies on garden cress (Lepidium sativum L.) seeds in Wistar rats. Int J App Res Nat Prod. 2011;4(1):37-43.

\section{GRAPHICAL ABSTRACT}

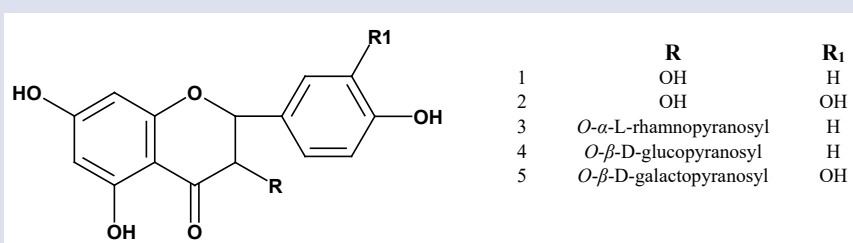

32. Hassan AM, Alam SS, Abdel-Aziem SH, Ahmed KA. Benzo-a-pyrene induced genotoxicity and cytotoxicity in germ cells of mice: Intervention of radish and cress. J Genet Eng Biotechnol. 2011;9:65-72.

33. Kassie F, Rabot S, Uhl M, Huber W, Qin HM, Helma C, Schulte -Hermann $\mathrm{R}$, et al. Chemoprotective effects of garden cress (Lepidium sativum) and its constituents towards 2-amino-3-methyl-imidazo (4,5-f) quinoline (IQ)induced genotoxic effects and colonic preneoplastic lesions. Carcenogenesis. 2002;23(7):1155-61.

34. Kassie F, Laky B, Gminski R, Mersch-Sundermann V, Scharf G, Lhoste E, et al Effects of garden and water cress juices and their constituents, benzyl and phenethylisothiocyanates, towards benzo(a)pyrene-induced DNA damage: a model study with the single cell gel electrophoresis/HepG ${ }_{2}$ assay. Chem Biol Interact. 2003;142:285-96.

35. Luca VS, Miron A, Aprotosoaie AC. The antigenotoxic potential of dietary flavonoids. Phytochem Rev. 2016;15:591-625.

36. Muthukumaran S, Sudheer AR, Menon VP, Nalini N. Protective effect of quercetin on nicotine-induced prooxidant and antioxidant imbalance and DNA damage in Wistar rats. Toxicology. 2008;243:207-15.

37. Fadda LM, Hagar H, Mohamed AM, Hanaa M, Ali HM. Quercetin and idebenone ameliorate oxidative stress, inflammation, DNA damage, and apoptosis induced by titanium dioxide nanoparticles in rat liver. Dose Response. 2018;16(4):1-9.

38. Edenharder R, Grunhage D. Free radical scavenging abilities of flavonoids as mechanism of protection against mutagenicity induced by tert-buty hydroperoxide or cumene hydroxide in Salmonella typhimurium. Mutat Res. 2003;540:1-18

39. Bhouri W, Sghaier MB, Kilani S, Bouhlel I, Dijoux-Franca MG, Ghedira $K_{\perp}$ et al. Evaluation of antioxidant and antigenotoxic activity of two flavonoids from Rhamnus alaternus L. (Rhamnaceae): Kaempferol 3-O- $\beta$-isorhamninoside and rhamnocitrin 3-O- $\beta$-isorhamninoside. Food Chem Toxicol. 2011;49:1167-73.

40. Zia-Ul-Haq M, Ahmad S, Calani L, Mazzeo T, Del Rio D, Pellegrini N, et al Compositional study and antioxidant potential of Ipomoea hederacea Jacq. and Lepidium sativum L. seeds. Molecules. 2012;17:10306-21.

41. Indumathy $R$, Aruna A. Free radical scavenging activities, total phenolic and flavonoid content of Lepidium sativum (Linn.) Int J Pharm and Pharm Sci. 2013;5(4):634-7.

42. Malar J, Chairman K, Singh ARJ, Vanmathi JS, Balasubramanian A, Vasanth K. Antioxidative activity of different parts of the plant Lepidium sativum Linn. Biotechnol Rep. 2014;3:95-8.

\section{SUMMARY}

Five known flavonoids were isolated from the methanolic seed extract of Lipidium sativum. Flavonoids from L. sativim inhibited the DNA damage induced by cyclophosphamide in somatic and germ cells of mice dose-dependently.

\section{ABOUT AUTHORS}

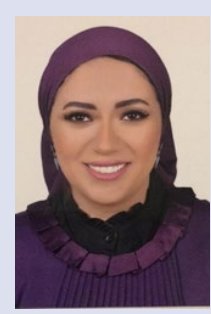

\section{Dr. Iman Kassem}

Iman Kassem works as a researcher at National Research Centre (Chemistry of Natural Compounds Department, Pharmaceutical and Drug Industries Research Division), Giza, Egypt and part-time lecturer in faculty of Pharmacy, Nahda University, Beni-Suef, Egypt. She received her BSc from faculty of Pharmacy, Ain Shams University. She also received her M.Sc. and Ph.D. from faculty of Pharmacy, Cairo University.

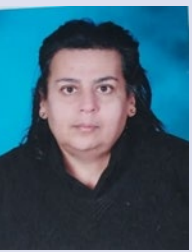

Ass. Prof. Neveen Sabry Ghaly

Associate professor since 2011. Published 15 publications in national and international journals. Participated in several research projects. 


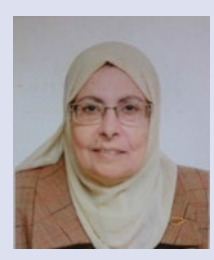

\section{Dr. Zeinab Mohammed Hassan}

Current Position: Researcher of Chemistry of natural Compounds, Chemistry of Natural Compounds Department, Pharmaceutical and Drug Industries Research Division, National Research Centre, Egypt.

Research Interest: Cytogenetic research.

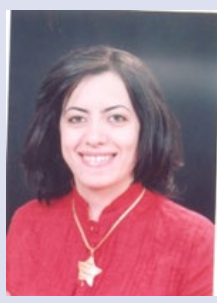

Dr. Marian Nabil Fekry

Current Position: Researcher of Chemistry of natural Compounds (since 2012), Chemistry of Natural Compounds Department, Pharmaceutical and Drug Industries Research Division, National Research Centre, Egypt.

\section{Research Interest:}

Natural Products Chemistry: Separation and purification of organic compounds using chromatographic techniques.

Advanced Spectroscopic Techniques for Organic Structures Identification: Identification of organic compounds using advanced NMR techniques (COSY, NOESY, HMBC, HMQC).

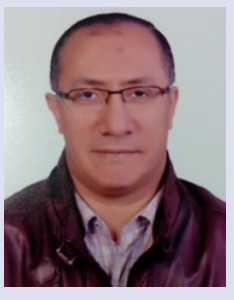

\section{Dr. Ayman Ali Farghaly}

Worked at National Research Centre since 1991 and has been a professor since 2012. Specialized in animals cytogenetic research. Participated in

16 scientific projects and published 35 international research papers. Citation 145 and h index 6.

Cite this article: Kassem IAA, Farghaly AA, Ghaly NS, Hassan ZM, Nabil M. Composition and Genoprotective Effect of the Flavonoidal Content of Lepidium sativum L. Methanolic Seed Extract against Cyclophosphamide- Induced DNA Damage in Mice. Pharmacog J. 2020;12(1):124-30. 